excellent manner in which this new arrangement of the Geological Museum has been carried out, and on the praiseworthy attempt to give every possible opportunity and convenience for the study of Geology in the great Northern Capital.

\title{
COREFSPONDENOF.
}

\section{THE MAMMOTH AND THE GLACIAL DRIFT.}

Sir,-From the lofty heights of literary criticism Sir Henry Howorth looks down upon the struggling company of practical geologists, and seems to think that he gains a much better view of the problems to be solved than those who are toiling among the inequalities of the plain below.

'The toilers on the plain, however, will be apt to think that they can perceive the structure of these inequalities better than the man who surveys them from such a distant standpoint, and when this person boldly proclaims from his mountain-top that the geologists are making great mistakes they will naturally ask him if he has ever taken a nearer view of the deposits he points to. Now it does not appear that Sir Henry Howorth has had any practical experience as a geologist; he evidently has a considerable acquaintance with the literature of Pleistocene geology, but geologists cannot accept this as a sufficient qualification for dealing with such a difficult subject as the relative ages of British Pleistocene deposits. His lack of practical acquaintance with the deposits he is writing about shows itself on page 400, where he quotes Prof. Flower's discovery of flint implements "at Thetford on the Ouse" as bearing on the age of the gravels in the valley of the Ouse near Bedford! Is it possible that from his lofty standpoint Norfolk and Bedfordshire seem close together?

It is of course perfectly logical to form a theory and then to see if it harmonises with the facts, but if he imagines that he has exhausted the data on which geologists ground their belief that some of the mammaliferous gravels are of later date than the East Anglian Boulder-clays, he is very much mistaken, and his claim to have proved that deposits containing the Mammoth fauna are never underlain by Glacial Drift is simply preposterous.

To disprove a universal negative a single case is of course sufficient, and be actually quotes such a case withont recognizing it as such. This is the section near Burgh, in Lincolnshire, where gravel with mammalian bones is intercalated between two sheets of Boulder-clay, the lower bed or " marl" being really the main mass of Boulder-clay. Whether my description of the locality fails to make this clear to the reader I cannot say, for I have not a copy of the memoir with me in the country.

I believe, too, though here I do not speak from personal knowledge, that there is no doubt about the superposition of the brickearth at Hoxne. Mr. H. B. Woodward distinctly states that the section he saw in 1878 had chalky Boulder-clay beneath it, ${ }^{1}$ though

1 Geology of England and Wales, 1887, p. 515. 
he admits that small pockets of such clay were also seen above it. Why does Sir Henry Howorth only quote the latter statement and not the former?

If Sir Henry will study the facts in the field, and especially if he will have a few excavations made at any of the localities where the relative age of the beds is doubtful, he will earn the gratitude of geologists, but his present methods of controversy do not entitle him to their respect.

There is an excellent field for research at Brandon; it is easy to prove that some of the brick-earths pass under the Boulder-clay, but there still remain two points to be decided, (1) do such brickearths contain flint implements? (2) are there not other deposits containing flint implements and mammalian remains which rest on this Boulder-clay?

Let Sir Henry Howorth do for Geology what General Pitt-Rivers has done for Archæology, and we will welcome the results. Meantime any further endeavour to support a preconceived theory by a partial examination of written statements will hardly be welcome to readers of this Magazine.

September 5th, 1892.

A. J. Jukes-Browne.

SHAPES OF SAND GRAINS.

SrR,-It is pleasant to hear from so experienced an observer as Mr. Cecil Carus-Wilson that the views expressed in my paper on Glacial Geology on the generally superior roundness of Marine Sands as compared with river sands are borne out by his own independent observations.

My remarks on the rounding of sand grains were strictly limited to its bearing on glacial geology. The sand-dunes referred to were those of our own coast. Here from Crosby to Southport we have 23 square miles of Blown sand which $I$ have been living on and working in as an engineer for the last 25 years. I can find no detectable difference in form between the saud grains of the shore and those of the dunes.

Desert sands are of course out of the question in glacial geology, and I quite agree with Mr. Carus-Wilson's observations relative to them. His other interesting observations shall have my attention in future work.

I have found my sand investigations of the greatest use in glacial geology, though not originally undertaken for that purpose. The polish in some of the glacio-marine sand grains is quite remarkable. No glacial shelly sands that I have examined fail to show much rounding of the grains-not only those quartz but the undoubted glacially derived materials also. There are also other glacial shelless sands of which there are the most convincing evidences of marine origin that exhibit equal evidences of extreme attrition.

The non-marine but purely glacial sands are invariably angular. I have just received from Professor J. J. Stevenson, of New York, a sample of sand from Glacier Bay in front of the Muir Glacier, Alaska, which is remarkably angular in grain. 